\title{
Patients with coronary artery disease and diabetes need improved management: a report from the EUROASPIRE IV survey: a registry from the EuroObservational
} Research Programme of the European Society of Cardiology

Viveca Gyberg 1,2, Dirk De Bacquer ${ }^{3,4}$, Guy De Backer ${ }^{3,4}$, Catriona Jennings ${ }^{3,5}$, Kornelia Kotseva ${ }^{3,5}$, Linda Mellbin 1,3, Oliver Schnell ${ }^{6}$, Jaakko Tuomilehto ${ }^{3,7,8,9,10}$, David Wood ${ }^{3,5}$, Lars Rydén ${ }^{1,3^{*}}$, Philippe Amouyel ${ }^{11}$, Jan Bruthans ${ }^{3,12}$, Almudena Castro Conde ${ }^{13}$, Renata Cifkova ${ }^{3,12}$, Jaap W. Deckers ${ }^{3,14}$, Johan De Sutter ${ }^{3,15}$, Mirza Dilic 3,16, Maryna Dolzhenko ${ }^{17}$, Andrejs Erglis 3,18, Zlatko Fras 3,19,20, Dan Gaita ${ }^{3,21}$, Nina Gotcheva ${ }^{22}$, John Goudevenos 3,23, Peter Heuschmann ${ }^{24,25,26}$, Aleksandras Laucevicius ${ }^{3,27,28}$, Seppo Lehto ${ }^{29}$, Dragan Lovic ${ }^{3,30}$, Davor Miličić3,31, David Moore ${ }^{32}$, Evagoras Nicolaides ${ }^{3,33}$, Raphael Oganov ${ }^{34}$, Andrzej Pająk ${ }^{35}$, Nana Pogosova,36, Zeljko Reiner ${ }^{3,37}$, Martin Stagmo ${ }^{38}$, Stefan Störk ${ }^{39}$, Lale Tokgözoğlu ${ }^{3,40}$, Dusko Vulic ${ }^{41}$ and On behalf of the EUROASPIRE Investigators

\begin{abstract}
Background: In order to influence every day clinical practice professional organisations issue management guidelines. Cross-sectional surveys are used to evaluate the implementation of such guidelines. The present survey investigated screening for glucose perturbations in people with coronary artery disease and compared patients with known and newly detected type 2 diabetes with those without diabetes in terms of their life-style and pharmacological risk factor management in relation to contemporary European guidelines.

Methods: A total of 6187 patients (18-80 years) with coronary artery disease and known glycaemic status based on a self reported history of diabetes (previously known diabetes) or the results of an oral glucose tolerance test and $\mathrm{HbA1c}$ (no diabetes or newly diagnosed diabetes) were investigated in EUROASPIRE IV including patients in 24 European countries 2012-2013. The patients were interviewed and investigated in order to enable a comparison between their actual risk factor control with that recommended in current European management guidelines and the outcome in previously conducted surveys.
\end{abstract}

Results: A total of 2846 (46\%) patients had no diabetes, 1158 (19\%) newly diagnosed diabetes and 2183 (35\%) previously known diabetes. The combined use of all four cardioprotective drugs in these groups was 53,55 and $60 \%$, respectively. A blood pressure target of $<140 / 90 \mathrm{mmHg}$ was achieved in $68,61,54 \%$ and a LDL-cholesterol target of $<1.8 \mathrm{mmol} / \mathrm{L}$ in 16,18 and $28 \%$. Patients with newly diagnosed and previously known diabetes reached an $\mathrm{HbA} 1 \mathrm{c}$ $<7.0 \%$ (53 mmol/mol) in 95 and $53 \%$ and $11 \%$ of those with previously known diabetes had an $\mathrm{HbA} 1 \mathrm{c}>9.0 \%$

\footnotetext{
*Correspondence: Lars.Ryden@ki.se

${ }^{3}$ European Society of Cardiology, Les Templiers, 2035 route des Colles,

CS 80179 BIOT, 06903 Sophia Antipolis Cedex, France

Full list of author information is available at the end of the article
} 
(>75 mmol/mol). Of the patients with diabetes $69 \%$ reported on low physical activity. The proportion of patients participating in cardiac rehabilitation programmes was low $(\approx 40 \%)$ and only $27 \%$ of those with diabetes had attended diabetes schools. Compared with data from previous surveys the use of cardioprotective drugs had increased and more patients were achieving the risk factor treatment targets.

Conclusions: Despite advances in patient management there is further potential to improve both the detection and management of patients with diabetes and coronary artery disease.

Keywords: Coronary artery disease, Type 2 diabetes, Secondary prevention, Management, Guideline adherence, Blood lipids, Blood pressure, Glycaemic control

\section{Background}

The backbone of clinical practice should be evidence derived from research and not least prospective, randomised, controlled clinical trials. An important tool for distributing contemporary knowledge is guidelines written by experts in various fields of medicine. The management of patients with coronary artery disease has since long been the subject of such guidelines.

One third of patients with coronary artery disease have diabetes, a rapidly growing disease globally [1-3]. Patients with both diagnoses have a considerably higher mortality than coronary patients without diabetes $[4,5]$. A comprehensive, target driven lifestyle and pharmacological strategy improve their prognosis to be almost similar to that of patients without diabetes $[6,7]$. Still preventive management of cardiovascular patients, especially those with diabetes, remains inadequate [6-8].

The European Society of Cardiology has issued guidelines on cardiovascular prevention in clinical practice since 1994 with the aim to improve the practice of preventive cardiology. The EUROASPIRE (European Action on Secondary and Primary Prevention by Intervention to Reduce Events) cross sectional surveys have since 1995, evaluated the implementation of these guidelines [9]. A similar survey, the EuroHeart Survey on Diabetes and the Heart [7] focused on patients with diabetes. Educational activities and updates of guidelines have been based on the outcome of these surveys with the intention to further improve every day practice. A follow up of the outcome of these efforts is important to provide feed back on aspects of cardiovascular prevention in need of further refinement.

The aim of the present investigation was to study screening for glucose perturbations in people with coronary artery disease and to compare life-style and pharmacological risk factor management in patients with known and newly detected type 2 diabetes with those without diabetes in relation to European Guidelines on prevention and the management of diabetes and its prestates issued in 2007, 2012 and 2013 [9-11].

\section{Methods}

EUROASPIRE IV was conducted at 79 centres in 24 European countries during May 2012 to April 2013 [12]. Men and women aged $\geq 18$ to $<80$ years were identified by the following diagnoses of first or recurrent coronary artery disease at a time $6-36$ months prior to the present investigation: (1) coronary artery bypass grafting (CABG), (2) percutaneous coronary intervention (PCI), (3) acute myocardial infarction (AMI), and (4) acute myocardial ischemia.

Information on personal and demographic details, self reported lifestyle and medication were obtained during an outpatient visit at the participating centres. Data collectors were trained to use standardized methodologies for physical measurements.

The following variables were recorded:

Height and weight were measured in light indoor clothes without shoes (scales 701 and measuring stick model 220; SECA Medical Measuring Systems and Scales, Birmingham, UK).

Waist circumference was measured using a metal tape applied horizontally at the point midway in the mid-axillary line between the lowest rim of the rib cage and the tip of the hip bone (superior iliac crest) with the patient standing [13]. Central obesity was defined as a waist circumference of $\geq 88 \mathrm{~cm}$ for women and $\geq 102 \mathrm{~cm}$ for men.

Blood pressure was measured twice on the right upper arm in the sitting position using an automatic digital sphygmomanometer (Omron M6; OMRON Corporation, Kyoto, Japan) and the mean was used for the analyses.

Physical activity was assessed by means of the International Physical Activity Questionnaire (IPAQ; IPAQ core group, Karolinska Institutet, Stockholm, Sweden).

Smoking at the time of interview was defined as selfreported smoking, and/or a breath carbon monoxide exceeding 10 ppm (Bedfont Scientific, Model Micro+) [14].

Blood lipids were measured in the fasting state and analysed at the central laboratory (Disease Risk Unit, National Institute for Health and Welfare, Helsinki, Finland) on a clinical chemistry analyser (Abbot Architect 
analyzer; Abbott Laboratories, Abbott Park, IL, USA) using enzymatic method for measuring total cholesterol.

Glycated haemoglobin A1c (HbA1c) was measured at a central laboratory with an immunoturbidimetric method (Abbot Architect analyzer; Abbott Laboratories, Abbott Park, IL, USA) in fasting venous whole blood sampled in an EDTA-tube.

An oral glucose tolerance test (OGTT) was performed using 75 grams of glucose in $200 \mathrm{~mL}$ of water in the morning after at least $10 \mathrm{~h}$ of fasting. Blood for fasting plasma glucose $(F P G)$ was drawn before intake of glucose with a dip safe from the EDTAtube in which the HbA1c was collected. Samples for the $2 \mathrm{~h}$ post-load glucose ( $2 \mathrm{hPG}$ ) measurement was drawn from whole venous blood using an EDTA-tube. Plasma glucose was analysed locally in all centres with a photometric point-of-care technique (Glucose 201, HemoCue ${ }^{\circledR}$, Ängelholm, Sweden) [15]. The HemoCue ${ }^{\circledR}$ method is cholesterol sensitive due to the measurement in very small volumes with higher levels of glycaemia at low cholesterol levels; therefore the glucose values were corrected for cholesterol according to the formula: HemoCue ${ }^{\circledR}$ glucose $+0.22 \times$ (total cholesterol - 5). Prior to final data analysis the values were converted from whole venous blood to plasma applying the formula established by Carstensen et al. [16]: plasma glucose $=0.558+0.119 \times$ whole blood glucose. Proper use of the equipment was assured through central training of the data collectors, and retrieval of HemoCue ${ }^{\circledR}$-cuvette storage information and validation sheets from a selection of the participating centres.

The use of four cardioprotective drug therapies consisting of antiplatelet drugs, $\beta$-blockade, renin-angiotensin-aldosterone-system (RAAS) blockade (including angiotensin converting enzyme inhibitors and angiotensin receptor blockers) and statins was assessed at the outpatient visit.

Treatment target attainment was assessed for blood pressure, LDL-cholesterol and HbA1c as outlined in Table 1.
Information on health care providers including participation in educational programmes involving physical activity, dietary advice and instructions on medications.

\section{Patient groups}

The participants were divided into three groups based on their glycaemic state:

\section{No diabetes}

No history of diabetes and all three tests FPG, 2hPG and $\mathrm{HbA1c}$ fulfilling the following criteria: FPG $<7.0 \mathrm{mmol} / \mathrm{L}$ $(126 \mathrm{mg} / \mathrm{dL})$ and $2 \mathrm{hPG}$ value $<11.1 \mathrm{mmol} / \mathrm{L}(200 \mathrm{mg} / \mathrm{dL})$ and $\mathrm{HbA} 1 \mathrm{c}<48 \mathrm{mmol} / \mathrm{mol}(<6.5 \%$; Diabetes Control and Complications Trial [DCCT]-standard).

\section{Newly diagnosed diabetes}

No history of diabetes and at least one of the three tests FPG, HbA1c and 2hPG fulfilling the following criteria: $\mathrm{FPG} \geq 7.0 \mathrm{mmol} / \mathrm{L}(126 \mathrm{mg} / \mathrm{dL})$ and/or $2 \mathrm{hPG}$ value $\geq 11.1 \mathrm{mmol} / \mathrm{L}(200 \mathrm{mg} / \mathrm{dL})$ and/or HbA1c $\geq 48 \mathrm{mmol} /$ mol ( $\geq 6.5 \%$; DCCT standard)

\section{Previously known diabetes}

A self-reported history of diabetes and/or prescribed glucose lowering drugs.

\section{Data management}

Data were collected electronically and submitted online to the data management centre (EuroObservational Research Program for EUROASPIRE IV, European Heart House, Sophia Antipolis, France). Data were checked for completeness, internal consistency and accuracy. All data were stored under the provisions of the National Data Protection Regulations.

\section{Statistical analyses}

The distributions of patient characteristics across groups (Table 2) were compared according to the Kruskal-Wallis test and the Chi square test, respectively. Use of pharmacological treatments and healthcare providers consulted were statistically compared between groups according to

Table 1 Treatment targets according to the European Guidelines for Diabetes, Pre-Diabetes and Cardiovascular Disease as issued 2007 [10], and updated in 2013 [11] and European Guidelines on Cardiovascular Disease Prevention in clinical practice issued 2012 [9]

\begin{tabular}{llll}
\hline Variable & Diabetes 2007 & Prevention 2012 & Diabetes 2013 \\
\hline Blood pressure $(\mathrm{mm} \mathrm{Hg})$ (no diabetes) & $<140 / 90$ & $<140 / 90$ & $<140 / 90$ \\
Blood pressure $(\mathrm{mm} \mathrm{Hg})$ (diabetes) & $<130 / 80$ & $<140 / 80$ & $<140 / 85$ \\
$\mathrm{LDL}-$ cholesterol $\mathrm{mmol} / \mathrm{L}(\mathrm{mg} / \mathrm{dL})$ (no diabetes and diabetes) & $<1.8(<70)$ & $<1.8(<70)$ & $<1.8(<70)^{\mathrm{a}}$ \\
$\mathrm{HbA} 1 \mathrm{C} \%(\mathrm{mmol} / \mathrm{mol})$ (diabetes) & $\leq 6.5 \%(\leq 48)$ & $\leq 7.0 \%(\leq 53)$ & $\leq 7.0 \%(\leq 53)$ \\
\hline
\end{tabular}

a Or at least $\mathrm{a} \geq 50 \%$ LDL-cholesterol reduction if this target cannot be reached 
Table 2 Patient characteristics of the 6187 included and 1811 excluded patients

\begin{tabular}{|c|c|c|c|c|c|}
\hline \multirow[t]{2}{*}{ Variable } & \multicolumn{3}{|l|}{ Diabetes } & \multirow{2}{*}{$\begin{array}{l}P \text { value (difference } \\
\text { between groups) }\end{array}$} & \multirow{2}{*}{$\begin{array}{l}\text { Missing info } \\
n=1811\end{array}$} \\
\hline & $\begin{array}{l}\text { No } \\
n=2846\end{array}$ & $\begin{array}{l}\text { Newly diagnosed } \\
n=1158\end{array}$ & $\begin{array}{l}\text { Previously known } \\
n=2183\end{array}$ & & \\
\hline Participants (\%) & 46 & 19 & 35 & & \\
\hline \multicolumn{6}{|l|}{ Age (years) } \\
\hline Mean (SD) & $63(10.0)$ & $65(9.2)$ & $65(8.6)$ & $<0.0001$ & $64(9.6)$ \\
\hline$<50$ & $320(11)$ & $68(6)$ & $103(5)$ & & $191(11)$ \\
\hline $50-59$ & $714(25)$ & $263(23)$ & $451(21)$ & & $492(27)$ \\
\hline $60-69$ & $1026(36)$ & $437(38)$ & $900(41)$ & & $622(34)$ \\
\hline$>70$ & $786(28)$ & $390(34)$ & $730(33)$ & & $506(28)$ \\
\hline Sex & & & & 0.006 & \\
\hline Women & $674(24)$ & $268(23)$ & $594(27)$ & & $412(23)$ \\
\hline Men & $2172(76)$ & $890(77)$ & $1589(73)$ & & $1399(77)$ \\
\hline Smoker & $464(16)$ & $165(14)$ & $304(14)$ & 0.04 & $346(19)$ \\
\hline Body mass index, kg/m & $28(4.2)$ & $29(4.5)$ & $31(5.0)$ & $<0.0001$ & $29(4.7)$ \\
\hline$<25$ & $638(23)(n=2841)$ & $164(14)$ & $239(11)(n=2171)$ & & $384(21)(n=1792)$ \\
\hline $25-29.9$ & $1349(48)(n=2841)$ & $533(46)$ & $846(39)(n=2171)$ & & $818(46)(n=1792)$ \\
\hline$\geq 30$ & $854(30)(n=2841)$ & $461(40))$ & $1086(50)(n=2171)$ & & $590(33)(n=1792)$ \\
\hline Central obesity & $1439(51)(n=2806)$ & $724(63)(n=1146)$ & $1510(71)(n=2135)$ & $<0.0001$ & $895(51)(n=1768)$ \\
\hline $\begin{array}{l}\text { Low or moderate physical activity } \\
\text { (IPAQ questionnaire) }\end{array}$ & $1215(55)(n=2214)$ & $484(54)(n=901)$ & $1079(69)(n=1667)$ & $<0.0001$ & $754(57)(n=1318)$ \\
\hline FPG mmol/L [mean (SD)] & $6.0(0.6)$ & $7.3(0.9)$ & $8.6(2.9)$ & $<0.0001$ & $6.1(1.7)$ \\
\hline 2hPG mmol/L [mean (SD)] & $7.1(1.7)$ & $10.1(3.4)$ & - & $<0.0001$ & - \\
\hline $\mathrm{HbA} 1 \mathrm{c} \mathrm{mmol} / \mathrm{mol}$ [mean (SD)] & $5.6(0.3)$ & $6.0(0.6)$ & $7.2(1.4)$ & $<0.0001$ & $5.8(0.7)$ \\
\hline
\end{tabular}

Data presented are $\mathrm{n}(\%)$ if not stated otherwise. In case of missing data the total number of observations is given in below the $\mathrm{n}(\%)$ information

multilevel logistic modelling to account for the clustering of patients within centres [17]. Distributions of blood pressures, LDL cholesterol and HbA1c levels in patients with diabetes, were compared through multilevel linear modelling. All models included age and sex as covariates, A level of alpha $<0.05$ was a priori chosen to indicate statistical significance. All statistical analyses were performed at the Department of Public Health, Ghent University, Belgium by means of SAS statistical software release 9.3 (SAS Institute Inc., Cary, NC, USA).

\section{Ethics}

National Co-ordinators were responsible for obtaining Local Research Ethics Committees approvals. Written, informed consent was obtained from each participant by the investigator by means of a signed declaration. The research assistants signed in the Case Record Form to confirm that informed consent was obtained and stored the original of the signed declaration of consent in the patient file.

\section{Results}

A total of 16,426 medical records were reviewed in the search for study participants and 7998 (49\%) attended the interview. The reasons for 8428 non-participants were as follows: no response to the invitation letter (35\%), refusal to attend for personal reasons (39\%), changing medical condition or deceased (16\%), living outside the catchment area (3\%) and miscellaneous (7\%). The median time between the index event and the interview was 16 months (interquartile range 12-22 months). Full information on the glycaemic state was available in 6187 (77\%) of the participants who attended the interview out of whom 2846 (46\%) had no diabetes, 1158 (19\%) had newly diagnosed diabetes and 2183 (35\%) had previously known diabetes, the vast majority with type 2 and only 41 with type 1 diabetes. Clinical characteristics of the patients with $(\mathrm{n}=6187)$ and without $(\mathrm{n}=1811)$ known glycaemic state at the time of interview are presented in Table 2.

There were small differences between the three groups regarding the use of antiplatelet agents (predominantly aspirin), $\beta$-blockers, RAAS-blockers and statins. A combination of all four cardioprotective drug classes was prescribed to $\leq 60 \%$ of the patients (Fig. 1).

\section{Glucose lowering treatment}

Sixty five per cent of the patients with previously known diabetes had been given dietary advice. The most 


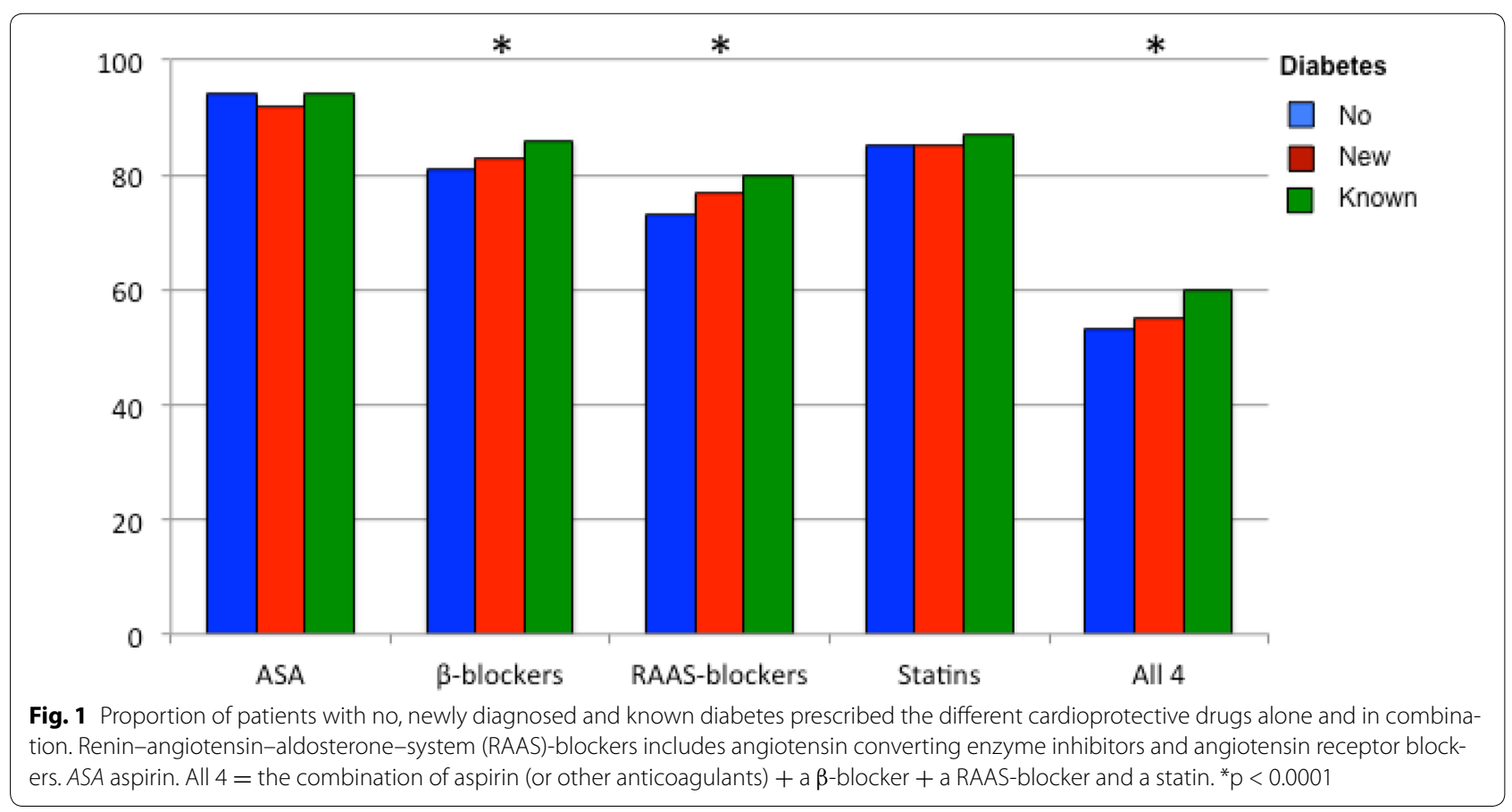

commonly used glucose lowering drugs in patients with previously known diabetes were metformin (57 \%), insulin (27\%), sulfonylurea (25\%) and DPP-4 inhibitor $(7 \%)$. The most common combinations of glucose lowering drugs were metformin + sulfonylurea (15\%), metformin + insulin (11\%) and metformin + DPP-4 inhibitor (6\%). The vast majority of patients $(97 \%)$ in all three groups responded that they seldom or never altered or missed their medication.

\section{Target achievement}

The proportion of patients with no, newly diagnosed and previously known diabetes reaching a blood pressure target of $<150 / 100,<140 / 90 \mathrm{mmHg}$ (target for patients with no diabetes 2012 [9]) and the target of $<130 / 80 \mathrm{mmHg}$ (target for patients with diabetes 2007 [10]) is presented in Fig. 2a. A blood pressure below $110 \mathrm{~mm} \mathrm{Hg}$ was observed among $5 \%$ of the patients.

The corresponding proportions of the three patient categories reaching the LDL-cholesterol target of $<1.8 \mathrm{mmol} / \mathrm{L}$ (target for all patients with established cardiovascular disease 2007 [10], 2012 [9] and 2013 [11]) is presented in Fig. 2b. The LDL-cholesterol exceeded $3.0 \mathrm{mmol} / \mathrm{L}$ in 26,26 and $17 \%$ of patients with no, newly diagnosed and previously known diabetes, respectively. Total cholesterol $<4.5 \mathrm{mmol} / \mathrm{L}$ (target for all patients with cardiovascular disease 2007 [10] and 2013 [11]) was reached in 59, 59 and $68 \%$. Patients with newly diagnosed and previously known diabetes had HbA1c $<7.0 \%$
(53 mmol $/ \mathrm{mol}$ ) in 95 and in $53 \%$, respectively. The proportion of patients with previously known diabetes that had an $\mathrm{HbA} 1 \mathrm{c}>9.0 \%$ (>75 mmol/mol) was $11 \%$.

\section{Health care providers}

An overview of healthcare providers is presented in Table 3 . Twenty seven per cent of the patients with previously known diabetes had attended a diabetes clinic.

\section{Discussion}

The three main findings in this first survey evaluating whether European Guidelines for Diabetes, Prediabetes and Cardiovascular Disease in 2007 [10] had an impact on the management of such patients are: (1) about one fifth of the participants had previously undetected diabetes. The failure to screen for diabetes when these coronary patients were first seen, 1-2 years before the interview, led to a lost opportunity to institute early and effective preventive measures in a particularly vulnerable group of patients; (2) although the combined use of four cardioprotective drug classes compares favourably with the proportions seen in previous surveys, a considerable proportion of the present patient population still does not reach guideline recommended treatment targets of blood pressure, blood lipids and of glycaemic control; (3) life style adaptation was poor among many patients as exemplified by a majority reporting low physical activity and in general low participation in cardiac rehabilitation programmes and diabetes clinics for those with known 


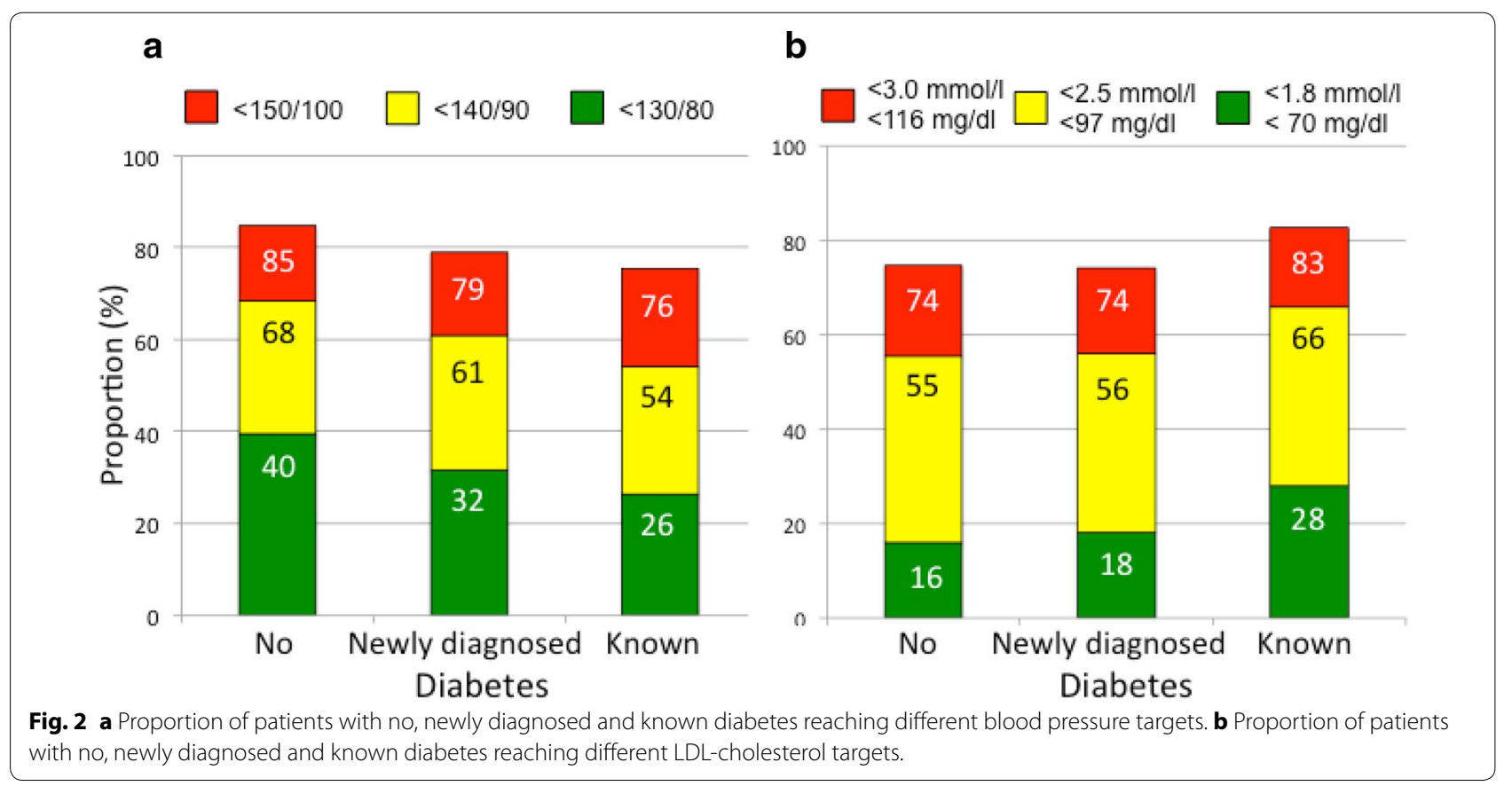

Table 3 Health-care provider delivering the care presented as $\%$ ( $\mathbf{n} /$ total $\mathbf{n}$ ) multiple health-care providers are possible explaining that columns add $>100 \%$

\begin{tabular}{|c|c|c|c|c|}
\hline \multirow[t]{2}{*}{ Health-care provider } & \multicolumn{4}{|l|}{ Diabetes } \\
\hline & No & Newly diagnosed & Previously known & P value $^{a}$ \\
\hline General practitioner & $58(1662 / 2845)$ & $62(717 / 1158)$ & $65(1408 / 2183)$ & 0.07 \\
\hline Cardiologist & $67(1916 / 2846)$ & $73(848 / 1158)$ & $74(1618 / 2183)$ & 0.69 \\
\hline Endocrinologist/diabetologist & $1(40 / 2846)$ & $2(18 / 1158)$ & $34(731 / 2183)$ & $<0.0001$ \\
\hline Cardiac specialist nurse & $5(134 / 2846)$ & $3(30 / 1158)$ & $5(114 / 2183)$ & 0.001 \\
\hline Cardiac rehabilitation program & $43(1201 / 2824)$ & $39(451 / 1145)$ & $36(777 / 2154)$ & $<0.0001$ \\
\hline
\end{tabular}

a Taking into account clustering of patients within centres and adjusted for age and sex

diabetes. It can therefore be stated that even if the 2007 European guidelines had some impact on patient management there is still a considerable potential to reduce the cardiovascular risk in patients with coronary artery disease and diabetes just by adhering to available knowledge as reflected in management guidelines, the most recent issued in 2013 [11].

The proportions of patients with newly diagnosed (19\%) and previously known diabetes (35\%) were similar to those reported in EuroHeart Survey of Diabetes and the Heart (14 and $31 \%$, respectively). Guideline recommendation is to screen systematically for diabetes in all coronary patients without self-reported diabetes [11]. This recommendation was not followed at the time for the index coronary event. In the present cohort a vast majority of the patients with newly diagnosed diabetes had an $\mathrm{HbA} 1 \mathrm{c}$ of $<6.5 \%(<48 \mathrm{mmol} / \mathrm{mol})$ underlining the need for an OGTT if FPG and HbA1c are negative as recently reported [18].

Blood pressure control was better compared to EUROASPIRE III and best in patients without diabetes. The proportions of patients with no diabetes, newly diagnosed diabetes and previously known diabetes achieving a target of $<140 / 90 \mathrm{~mm} \mathrm{Hg}$ was 52,49 and $43 \%$ in EUROASPIRE III [8] and 68, 61 and 54\% in the present survey. Both surveys reflect the difficulties in controlling blood pressure in patients with diabetes, who often require a combination of several different blood pressure lowering drugs. Even if patients with diabetes had the highest use of both RAAS-blockers and $\beta$-blockers 
it seems that their antihypertensive therapy needs to be strengthened [19]. Insufficient patient compliance may have contributed even if a majority of patients denied such behaviour. Unfortunately the available information does not allow a more detailed analysis of this possibility. An unexpected, but important, observation is that a group of patients had blood pressure levels well below guideline recommended targets. This finding should induce caution in consideration of the J-shaped curve of blood pressure control, with increasing cardiovascular events among coronary patients with a blood pressure consistently below the recommended level [20].

Of patients with no, newly diagnosed and previously known diabetes 12,11 and $20 \%$ reached a LDL-cholesterol target of $<1.8 \mathrm{mmol} / \mathrm{L}$ in EUROASPIRE III [8]. The corresponding proportions were 16, 18 and $28 \%$. Anyhow lipid management could undoubtedly have been further improved given that the target of $<1.8 \mathrm{mmol} / \mathrm{L}$ was recommended already 5-6 years before the initiation of the present survey [10]. As demonstrated by the Euro Heart Survey on Diabetes and the Heart [6] and the STENO 2 trial [21] adequate blood pressure and LDLcholesterol control is of critical importance for patients with diabetes. From the latter study it emerged that lipid control accounted for $73 \%$ of the observed decrease in morbidity and mortality while the corresponding impact of blood pressure and glucose control was 11 and $13 \%$, respectively [22]. Furthermore, lipid control is important not only for macro- but also microvascular complications in patients with diabetes [23, 24].

Glycaemic control in patients with previously known diabetes was similar to that observed in EUROASPIRE III $[8,25]$. Considering the risk of micro- and macrovascular complications $[26,27]$ it is of great concern that $10 \%$ of patients with known diabetes had an HbA1c $>9.0 \%$ (75 mmol/mol). It has become apparent from randomised trials that the reduction of macrovascular events by glucose-lowering strategies has yet to be proven and may only be seen after many years of follow-up [21, 28].

The rationale for not only reporting the total proportion of patients above the presently recommended target but also at more elevated levels was to show that large proportions have considerably higher cholesterol, blood pressure and glucose levels and to verify that the present findings were not related to patients being just above the recommended target.

There was no difference between EUROASPIRE III and IV in how many patients had a cardiologist as their health-care provider but the proportion of patients seen by a general practitioner was higher as was the proportion of patients with previously known diabetes seen by an endocrinologist. This changing pattern of caregivers may at least explain, to some extent, the improved management. On the negative side only $3-5 \%$ of the present patient cohort attended nurse led prevention programmes and less than one third of patients with diabetes had been offered specialist diabetes education.

A likely contributor to the observed improvement is the emphasis on the poor prognosis for patients with a combination of diabetes and coronary heart disease as reflected in the first Joint European Guidelines on diabetes, pre-diabetes and cardiovascular diseases issued in 2007 [10]. In an evaluation of the use of these guidelines almost nine out of 10 physicians, mainly general practitioners and internists, had the guidelines at their work place, and eight out of 10 were aware of and applied them in their daily practice [29].

Diabetes schools and comprehensive cardiovascular rehabilitation is achievable and efficient and has the potential to improve treatment given patient participation $[9,30]$. The under use of such programmes is a plausible explanation for the poor control of life-style oriented factors with a high proportion of obesity, low physical activity in a majority, and an unfortunate $14-16 \%$ of the patients still smoking. Moe et al. [31] recently studied the impact of physical activity on cardiovascular mortality in a large cohort of people with and without diabetes followed during 24 years. Inactive people with diabetes, especially those on medical treatment, had a significantly increased mortality risk compared with those who reported taking weekly physical exercise of at least $2 \mathrm{~h}$. This underlines the seriousness of the present findings indicating inertia and neglected efforts to improve lifestyle habits not least physical activity.

\section{Strengths and limitations}

Participating centres included university teaching hospitals, specialist cardiac centres and some district hospitals. Volunteer participation in a survey may indicate a particular interest in cardiovascular prevention. This bias is conservative as the standard of care in participating centres interested in prevention is likely to be high while care of patients in everyday practice is probably worse. The average interview rate was rather low, $49 \%$. Usually nonparticipants are more likely to have unhealthy lifestyles and the present data, if anything, may overestimate the true standard of preventive medicine across Europe. As can be seen in Table 2 the patients without full glycaemic information were more similar to those with no diabetes, which may have led to some overestimation of the proportions of known and newly detected diabetes. The fact is unlikely to affect the main conclusions of this survey considering the high prevalence of patients with glucose perturbations. The centres and countries participating in European Heart Survey of Diabetes and the Heart, EUROASPIRE III and IV are not the same, which has to 
be kept in mind when interpreting time trends. For logistic reasons only one sample of FPG, 2hPG and HbAlc was collected. A definite diagnosis of diabetes should be based on at least two measurements. Finally very few patients $(n=41)$ had type 1 diabetes making meaningful comparisons between them and those with type 2 diabetes impossible.

A main strength of EUROASPIRE IV is that data are based on interviews and standardized examinations rather than data from medical records, and that the survey despite a seemingly low participation rate provides comparative information on preventive care in a large cross-sectional European population of well-characterized individuals with coronary artery disease. The sample size allowed a statistically robust comparison between groups according to their glycaemic state. All three tests-FPG, 2hPG and HbA1c-as currently recommended for the classification of patients into their respective glycaemic category, were used thereby avoiding misclassification.

\section{Conclusion}

The prevalence of self reported diabetes underestimates the true prevalence of diabetes in coronary patients. A systematic approach to screen for diabetes in coronary patients is required. Although some of the risk factors studied were better controlled than in previous surveys, there is still considerable potential to further reduce cardiovascular risk through lifestyle and optimised cardioprotective medications in patients with diabetes and coronary artery disease through implementation of knowledge into every day clinical practice. This is particularly so for LDL-cholesterol where a large majority of patients do not reach the treatment target of $<1.8 \mathrm{mmol} / \mathrm{L}$ but blood pressure and glycaemic control also need further refinement.

\section{Authors' contributions \\ Study concept and design: VG, LR, DB. Acquisition, analysis, interpretation of data and approval for submission: all authors. Drafting of the manuscript: $V G$, $L R$, JT and OS. Critical revision of the manuscript: all authors. Statistical analysis: DB. Further information: see appendix. All authors read and approved the final manuscript.}

\footnotetext{
Author details

${ }^{1}$ Cardiology Unit, Department of Medicine, Karolinska Institutet, Karolinska University Hospital Solna, 17176 Stockholm, Sweden. ${ }^{2}$ Centre for Family Medicine, Department of Neurobiology, Care Sciences and Society, Karolinska Institutet, Huddinge, Sweden. ${ }^{3}$ European Society of Cardiology, Les Templiers, 2035 route des Colles, CS 80179 BIOT, 06903 Sophia Antipolis Cedex, France. ${ }^{4}$ Department of Public Health, Ghent University, Ghent, Belgium. ${ }^{5}$ Department of Cardiovascular Medicine, National Heart and Lung Institute, Imperial College London, London, UK. ${ }^{6}$ Forschergruppe Diabetes e.V. at the Helmholtz Center, Munich, Germany. ${ }^{7}$ Centre for Vascular Prevention, Danube-University Krems, Krems, Austria. ${ }^{8}$ Department of Chronic Disease Prevention, National Institute for Health and Welfare, Helsinki, Finland. ${ }^{9}$ Instituto de Investigacion Sanitaria del Hospital Universario LaPaz (IdiPAZ), Madrid, Spain. ${ }^{10}$ Diabetes Research Group, King Abdulaziz University, Jeddah, Saudi Arabia. ${ }^{11}$ Institut Pasteur de Lille, Inserm U744, Université Lille Nord de France, 1 rue du
}

Professeur Calmette B.P. 245, 59019 Lille, France. ${ }^{12}$ Center for Cardiovascular Prevention, 1st School of Medicine, Charles University and Thomayer Hospital, Vídeňská 800, 14059 Prague, Czech Republic. ${ }^{13}$ Cardiac Rehabilitation Unit, Cardiology Department, Hospital Universitario La Paz, Madrid, Spain. ${ }^{14}$ Thoraxcenter's Department of Cardiology, Dr Molewaterplein 50, 3000 DR Rotterdam, The Netherlands. ${ }^{15}$ Department of Internal Medicine, University of Ghent, De Pintelaan 185, 9000 Ghent, Belgium. ${ }^{16}$ Clinical Center University of Sarajevo, Bolnička 25, 71000 Sarajevo, Bosnia and Herzegovina. ${ }^{17}$ Department of Cardiology of Shupyk's Medical Academy of Postgraduate Education, 9 Dorohozhyts'ka str, Kiev 04112, Ukraine. ${ }^{18}$ University of Latvia, Pauls Stradins Clinical University Hospital, Pilsonu Street 13, Riga 1002, Latvia.

${ }^{19}$ Preventive Cardiology Unit, Division of Internal Medicine, University Medical Centre Ljubljana, Zaloška 7, 1525 Ljubljana, Slovenia. ${ }^{20}$ Medical Faculty, University of Ljubljana, Vrazov trg 2, 1000 Ljubljana, Slovenia. ${ }^{21}$ Institutul de Boli Cardiovasculare, Universitatea de Medicina si Farmacie "Victor Babes", Timisoara, Romania. ${ }^{22}$ Department of Cardiology, National Heart Hospital, 65, Konyovitsa, 1309 Sofia, Bulgaria. ${ }^{23}$ Cardiology Department of Medical School, University of loannina, loannina, Greece. ${ }^{24}$ Institute of Clinical Epidemiology and Biometry, University of Würzburg, Würzburg, Germany. ${ }^{25}$ Comprehensive Heart Failure Center, University of Würzburg, Würzburg, Germany. ${ }^{26}$ Clinical Trial Center Würzburg, University Hospital Würzburg, Josef-Schneider-Str. 2, 97080 Würzburg, Germany. ${ }^{27}$ Clinic of Cardiovascular Diseases of Vilnius University, Santariskiu 2, 08661 Vilnius, Lithuania. ${ }^{28}$ Heart and Vascular Medicine of Vilnius University Hospital Santariskiu Clinics, Santariskiu 2, 08661 Vilnius, Lithuania. ${ }^{29}$ Kuopio University Hospital, Rakennus 5/6. Kerros, Puijonlaaksontie 2, 70210 Kuopio, Finland. ${ }^{30}$ Clinic for Internal Medicine Intermedica, Jovana Ristica 20/2, 18000 Nis, Serbia. ${ }^{31}$ University of Zagreb School of Medicine and University Hospital Centre Zagreb, Kispaticeva 12, HR-10000 Zagreb, Croatia. ${ }^{32}$ The Adelaide and Meath Hospital, Tallaght, Dublin 24, Ireland. ${ }^{33}$ University of Nicosia Medical School, Nicosia General Hospital, 2029 Strovolos, Nicosia, Cyprus. ${ }^{34}$ National Research Center for Preventive Medicine of the Ministry of Healthcare of the Russian Federation, 10 Petroverigsky per, 101990 Moscow, Russia. ${ }^{35}$ Department of Epidemiology and Population Studies, Faculty of Health Sciences, Jafiellonian University Medical College, Grzegórzecka 20, 31-531 Cracow, Poland. ${ }^{36}$ Federal Health Centre and Department of Chronic Noncommunicable Diseases Prevention, National Research Centre for Preventive Medicine, 10 Petroverigsky per, 101953 Moscow, Russia. ${ }^{37}$ University Hospital Centre Zagreb, School of Medicine, University of Zagreb, Kišpatićeva 12, 10000 Zagreb, Croatia. ${ }^{38}$ Department of Heart failure and Valve Disease, Skåne University Hospital, Lund, Sweden. ${ }^{39}$ Comprehensive Heart Failure Centre and Department of Medicine I, University of Würzburg, Straubmühlweg 2a, 97078 Würzburg, Germany. ${ }^{40}$ Hacettepe University, 06690 Ankara, Turkey. ${ }^{41}$ Centre for Medical Research, School of Medicine, University of Banja Luka, Vuka Karadzica 6, 78000 Banja Luka, Republic of Srpska, Bosnia and Herzegovina.

\section{Funding}

EUROASPIRE IV survey was carried out under the auspices of the EURObservational Research Programme of the European Society of Cardiology [32]. The survey were supported through unrestricted research Grants to the European Society of Cardiology from Amgen, AstraZeneca, Bristol-Myers Squibb, GlaxoSmithKline, F. Hoffman-La Roche and Merck Sharp \& Dohme. The equipment for glucose measurement was provided free of charge by the HemoCue ${ }^{\circledR}$ Company, Ängelholm, Sweden. The sponsors of the EUROASPIRE surveys had no role in the design, data collection, data analysis, data interpretation, and writing of this report. All authors had access to data, approved the manuscript and the submission for publication.

\section{EUROASPIRE Investigators}

EUROASPIRE was originally an initiative of the ESC Working Group on Epidemiology and Prevention and the first EUROASPIRE survey was undertaken as part of work of the Joint ESC/EAS/ESH Implementation Group on Coronary Prevention. The structure of the administrative organisation is described below followed by a list of participating study centres and organisations, and investigators and other research personnel.

Scientific Steering/Expert Committees: K Kotseva (London, UK, Chair EUROASPIRE IV Steering Committee), G De Backer (Ghent, Belgium, Chair EUROASPIRE IV Executive Committee), P Amouyel (Lille, France), J Bruthans (Prague, Czech Republic), A Castro Conde (Madrid, Spain), R Cifkova (Prague, Czech Republic), D De Bacquer (Ghent, Belgium), J De Sutter (Ghent, Belgium), J W Deckers (Rotterdam, Netherlands), M Dilic (Sarajevo, Bosnia and 
Herzegovina), M Dolzhenko (Kiev, Ukraine), A Erglis (Riga, Latvia), T Ferreira (Nice, France), Z Fraz (Ljubljana, Slovenia), D Gaita (Timisoara, Romania), S Gielen (Halle/Wittenberg, Germany), N Gotcheva (Sofia, Bulgaria), I Goudevenos (loannina, Greece), V Gyberg (Stockholm, Sweden), P Heuschmann (Würzburg, Germany), A Laucevicius (Vilnius, Lithuania), S Lehto (Kuopio, Finland), D Lovic (Nis, Serbia), M Manini (Nice, France), A P Maggioni (Florence, Italy), D Miličić (Zagreb, Croatia), D Moore (Dublin, Ireland), E Nicolaides (Nicosia, Cyprus), A Pajak (Cracow, Poland), N Pogosova (Moscow, Russia), Ž Reiner (Zagreb, Croatia), L Rydén (Stockholm, Sweden), O Schnell (Munich Neuherberg, Germany), M Stagmo (Malmo, Sweden), S Störk (Würzburg, Germany), J Sundvall (Helsinki, Finland), L Tokgözoğlu (Ankara, Turkey), J Tuomilehto (Helsinki, Finland), D Vulic (Banja Luka, Bosnia and Herzegovina), D Wood (Principal Investigator, London, UK).

Coordinating centre: Cardiovascular Medicine, International Centre for Circulatory Health, National Heart and Lung Institute, Medical Faculty, Imperial College London, London, UK: D A Wood, K Kotseva, C Jennings, A Adamska.

Diabetes centre: Department of Cardiology, Karolinska University Hospital, Stockholm, Sweden: L Rydén, V Gyberg, J Tuomilehto, O Schnell.

Data management centre: EURObservational Research Programme Department, European Society of Cardiology, Sophia Antipolis, Nice, France: A P Maggioni, T Ferreira, M Manini, C Tylor, M Konte, M Glemot.

Computing and statistical centre: Department of Public Health, Ghent University, Belgium: D De Bacquer, G De Backer.

Central laboratory: Disease Risk Unit, National INstitute for Health and Welfare, Helsinki, Finland. J Sundvall, L Lung, J Leviviskä.

Study centres, organisations, investigators and other research personnel (National Co-ordinators in each country are indicated by asterix):

Belgium: University Hospital Ghent: D De Bacquer*, G De Backer, M De Pauw, C Ghysbrecht, P Vervaet; A Z Maria Middelares: J De Sutter*, S Pardaens, A M Willems; A Z Sint Lucas: P Cambier, R Claeys, N Deweerdt, J Nimmergeers, $\mathrm{H}$ Vandekerckhove, $\mathrm{H}$ Verloove, L Versee.

Bosnia and Herzegovina: Bosnia and Herzegovina Centre for Medical Research and Development Heath Care, Banja Luka: D Vulic*, D Djekic. Clinical Centre, Banja Luka: G Malesevic, S Pejicic, S Srdic. Clinical Centre University Sarajevo: M Dilic*, A Begic, E Hodsic, M Kulic, N Sabanovic-Bajrmovic, E Tahirovic. University Clinical Centre of Tuzla: Z Kusljugic, M Nurkic, I Iveljic, J Kovcic. Bulgaria: National Heart Hospital, Sofia: N Gotcheva*, V Baycheva, B Georgiev, G Vladimirov. Military Medical Academy: D Gotchev, S Ivanov.

Croatia: University Hospital Centre Zagreb, University of Zagreb School of Medicine: Ž Reiner*, D Miličić* , J Samardžić. University Hospital Centre Sestre Milosrdnice, Zagreb: B Perić. University Hospital Dubrava, Zagreb: M Sičaja.

Cyprus: Nicosia General Hopsital. E Nicolaides*, C Eftychiou, E Eteocleous, P Georgiou, C Hadjilouca, J A Moutiris, R Nicolaou, K Papadopoulos, M Patsalou.

Czech Republik: Center for Cardiovascular Prevention, Charles University in Prague, First Faculty of Medicine and Thomayer Hospital, Prague: J Bruthans*, R Cífková*, A Krajcoviechova, P Wohlfahrt; Department of Internal Medicine II, Faculty of Medicine in Pilsen, Charles University, Pilsen: J Filipovský, M Krizek, Z Kviderova, O Mayer, P Vágovičová, J Vanek, J Seidlerova, KTimoracká: Department for Preventive Cardiology, Institute of Clinical and Experimental Medicine, Prague: V Adamkova, J Belohoubek, M Galovcova, V Zelenkova.

Finland: Kuopio University Hospital: S Lehto*, E Kiljander, P Kiljander, P Kylmaoja H R Lehto, S Olkkonen; lisalmi Hospital: J Pennanen; Varkaus Hospital: M Herranen.

France: Institut Pasteur de Lille, Inserm U744, Université Lille Nord de France: P Amouyel*, A L Astolfi, S Balik, S Beauchant, J Dallongeville, C Devoghelaere, N Fievet, P Garboni, B Lemaire, N Marecaux, M Montaye; Hopital Saint Philibert, Lomme; Hopital Cardiologique, CHRU, Lille; Centre Hospitalier Gustave Dron, Tourcoing; Hopital Victor Provo, Roubaix.

Germany: Klinik Kitzinger Land: W Karmann, S Held. University of Würzburg: P Heuschmann*, K Eichstädt, L Deckert, D Fischer, A Gerhardt, J Kircher, Y Memmel, K Nolte, M Schich, V Wahl, M Wagner; University Hospital Würzburg: S Störk*, G Ertl, S Güntner, R Leyh.

Greece: Giannena University Hospital: I Goudevenos*, K Kalantzi. Athens Euroclinic: D Athanassias, G Goumas, P Krimbas, D Richter, D Sakellariou; Alexandra Hospital: J Agrios, I Matthaios, E Papadopoulou, S Toumanidis, E TsounaHatjis; AHEPA Hospital, Aristotle University: A Boufidou, K Makedou, L Lilis. Ireland: Tallaght Hospital: D Moore*, G Broderick, N Fallon, S Storey. Latvia: Daugavpils Regional Hospital: I Baronenko, G Dormidontova, A Dulkevica, V Dzerve; Pauls Stradins Clinical University Hospital: A Erglis*, T Andrejeva, N Bricina, J Jakovleva, A Jaunromane, E Keive, M Klovane, D Lurina,
L Makarova, D Matisone, I Mintale, E Pahomova-Strautina, L Putane, M Stabulniece, DVasiljevs, G Vevere, J Vilks.

Lithuania: Vilnius University Hospital Santariskiu Klinikos: A Laucevicus*, I Alitoit, J Badariene, I Grabliauskaite, I Jursyte, E Paleviciute, Z Petrulioniene, P Serpytis, R Serpytis, S Solovjova, V Smagriunaite. Hospital of Lithuanian Health Science University: R Babarskiene, I Ceponiene, O Gustiene, R Karaliute, E Rumbinaite, R Dlapikas, V Smalinskas, R Verseckaite.

Poland: Department of Epidemiology and Population Studie, Instittute of Public Health, Jagiellonian University Medical College, Kraków: A Pająk*, E Brzezicka, R Łysek, W Misowiec, R Wolfshaut-Wolak. Department of Coronary Disease, Institute of Cardiology, Jahiellonian University Medical College, John Paul II Hospital: J Nessler. Department of Cardias and Vascular Diseases, Institute of Cardiology, Jagielloninan University, Medical Collega, John Paul II Hospital: P Podolec. Department of Cardiology, J Dietl Hospital, Kraków: E Mirek-Bryniarska. Department of Cardiology, Narutowicz City Soecialty Hospital, Kraków: J Grodecki. 1st Department of Cardiology and Hypertension, Jagiellonian University Medical College, Kraków: D Czarnecka, A Łukaszewska, P Jankowski. Department of Cardiology, Ludwik Rydygier Memorial Specialized Hospital, Kraków: P Bogacki.

Romania: Universitatea de Medicina si Farmacie" $\bigvee$ Babes"Timisoara. Institutul de Boli Cardiovasculare Timisoara: D Gaita*, C Avram, E Barzuca, L Gaita, F Jurca-SImina, O C lancu, A Lazar, M lurcius, S lurciuc, M Mal, S Mancas, A Mihaescu, D Mociar, S Mosteoru, S Pescariu, L Petrescu, C Sasec, A Schiller. Universitatea de Medicina si Farmacie"C Davila"Bucuresti. Spitalul Universitar de Urgenta Bucuresti: L Amarie, A Andronic, S Calin, A Ciobanu, A Cotoban, S Guberna, L Lugeanu, D Mihalcea, N Niculescu, R Rimbas, C Udroiu, D Vinereanu.

Russia: National Research Centre for Preventive Medicine, Moscow: N Pogosova*, A Ausheva, S Boytov, A Kursakov, R Oganov. Moscow Reginal Cardiological Centre: Y Pozdnyakov, N Skazin.

Serbia: Clinic for internal disease InterMedica, Nis: D Lovic*, B lovic, M Nedeljkovic, M Ostojic. Cardiopulmonary Rehabilitation Clinical Centre Niska Banka: D Djordjevic, S Kostic, I Tasic. University Hospital Medical Centre"Bezanijska Kosa", Belgrade: M Zdravkovic. Institute for Rehabilitation, Belgrade: M Andić, T Fulupović, O llić-Stojanović, M Ješić-Jukić, N Jevsnik, M Lazović, A Radović, D Radović, D Rosić, D Spiroski, S Stevović, TVidaković, V Vuković-Dejanović

Slovenia University Medical Centre, Division of Internal Medicine, Ljubljana: Z Fras*, B Jug, A Juhant, A Poljancic, L Poljancic.

Spain: Hospital la Paz - Hospital Cantoblanco, Madrid: A Castro Conde*, R Dalmau Gonzalez-Gallarza, A M Iniesta Manjavacas.

Sweden: Skåne University Hospital, Malmö: M Stagmo*, H Jernhed, E Stensgaard; Karolinska Hospital, Stockholm: V Gyberg*, V Boström, C Edman Jönsson, C Hage.

The Netherlands: Thorax Centre, ERASMUS MC, Rotterdam: J W Deckers* S. Khatibi F, Yongzhao; Sint Franciscus Gasthuis, Rotterdam: M. Veerhoek; Maasstadziekenhuis, Rotterdam: P C Smits; Academic Medical Centre, University of Amsterdam, Amsterdam: M Minneboo, R J G Peters, W Scholte op Reimer, M Snaterse-Zuidam.

Turkey: Hacettepe Üniversitesi Tıp Fakültesi: L Tokgözoğlu*, S Asil, B Kaya, D Koçyiğit; Ankara Üniversitesi Tıp Fakültesi: Ç Erol, V Kozluca, C Tulunay Kaya; Đzmir Atatürk Eğitim ve Araştırma Hastanesi: Đ Akyıldız, O Ergene, E Varış; Dokuz Eylül Üniversitesi Tıp Fakültesi: B Akdeniz, Ö Göldeli, Ö Kozan, E Özpelit; Dr.Siyami Ersek Hastanesi Göğüs Kalp Cerrahi Merkezi: S Altay, N Çam, M Eren; Ege Üniversitesi Tıp Fakültesi: M Kayıkçıŏglu, H Kültürsay; Florance Nightingale Hospital: V Aytekin, A Burak Çatakoğlu; Gazi Üniversitesi Tıp Fakültesi: A Abacı, M Candemir, S Ünlü; Göztepe Eğitim Araştırma Hastanesi: A O ğuz; Gülhane Askeri Tıp Akademisi-ANKARA: C Barçın, S Yaşar, M Yokuşoğlu; Türkiye Yüksek Đhtisas Hastanesi: S Aydoğdu, A Temizhan, S Ünal; Đstanbul Üniversitesi Cerrahpaşa Tıp Fakültesi: H Altuğ Çakmak, M Çimci, Z Öngen; Gebze Anadolu Sağlık Merkezi: G Ateş, N Koylan; Đstanbul Üniversitesi Đstanbul Tıp Fakültesi: S Emet, B Umman; Đstanbul Üniversitesi Kardiyoloji Enstitüsü: C Bostan, V Sansoy; Đstanbul M.Akif Ersoy Kalp Ĕğitim ve Araştırma Hastanesi: M Kemal Erol, A Kemal Kalkan; Đstanbul Kartal Koşuyolu Ĕgitim ve Araştırma Hastanesi: C Kaymaz, N Poçi.

Ukraine: National Scientific Center "M.D. STRAZHESKO INSTITUTE OF CARDIOLOGY, MAS OF UKRAINE": M.Dolzhenko*, T Getman, L Konoplyanik, L Klimenko, L Lobach, Y Luchinskaya, L Lurie, M Lutay, E Mitchenko, O Nemchena, N Nosenko, N Perepelchenko, S Potashev, A Radchenko, V Romanov, V Shumakov, T Simagina, Y Sirenko, I Sychov. Kiev City Heart Centre: 
N Mohnacheva, A Verezhnikova, O Zharinov. SI"The institute of Gerontology namned after D F Chebotarev NAMS of Ukraine": V Lishnevskaya, I Mikropulo, V Prihodk, I Shapolvalenko.

United Kingdom: ICCH, Imperial College London: D Wood*, A Adamska, J Evans, K loannides, C Jennings, A Kasonta, K Kotseva, H Onyango, A Rapacz, B Wrotniak. Hillingdon Hospital, Middlesex: S Dubrey. Haefield Hospital, Middelsex: M Barbir. Charing Cross Hospital, London: S Connoly. Central Middlesex Hospital, London: M Dancy. Royal Brompton Hospital, London: P Collinc. West Middlesec Hospital, Isleworth: R Kaprielian.

\section{Compliance with ethical guidelines}

\section{Competing interests}

$\checkmark$ Gyberg reports lecture honorarium from MSD Sweden. D. De Bacquer, G. De Backer, C. Jennings and O. Schnell have nothing to declare. K. Kotseva reports Grants from European Society of Cardiology and travel Grants from Hoffman La Roche and Boehringer Ingelheim outside the submitted work. L. Mellbin reports other from MSD Sweden, other from Sanofi Aventis, Grants from Bayer AG, outside the submitted work. J. Tuomilehto reports Grants and fees from AstraZeneca, Grants and fees from Bayer Pharma, Grants from Boehringer Ingelheim, fees from Eli Lilly, fees from Impeto Medical, Grants and fees from Merck Serono, Grants and fees from MSD, fees from Novo Nordisk, Grants and fees from Novartis, Grants and fees from Sanofi-Aventis, Grants from Servier and Orion pharma outside the submitted work. D. Wood reports Grants from AstraZeneca, Bristol-Myers Squibb/Emea Sarl, GlaxoSmithKline, F. Hoffman-La Roche, and Merck, Sharp \& Dohme and fees from AstraZeneca, Merck Sharp and Dohme, Kowa Pharmaceuticals, Menarini, Zentiva, fees from Merck Sharp and Dohme outside the submitted work. L. Rydén reports Grants from The Swedish Heart-Lung Foundation and The European Society of Cardiology; fees from Roche, BMS and Sanofi-Aventis, Grants from Bayer, outside the submitted work. A. Castro Conde, A. Erglis, A. Laucevicius, D. Miličić, S. Lehto, D. Lovic, J. Deckers, J. De Sutter, J. Goudevenos, M. Stagmo, M. Dilic, N. Gotcheva, D. Vulic, L. Tokgözoğlu, N. Pogosova, D. Gaita, E. Nicolaides, R. Oganov and Z. Fras has nothing to disclose. A. Pająk was supported by a Grant from Polish National Science Centre (Contract DEC-2011/03/B/N27/06101) during the conduct of the study. D. Moore reports Grants from Servier, MSD, Sanofi-Aventis and A. Menarini during the conduct of the study R Cifkova and J Bruthans reports Grants from Internal Grant Agency of the Czech Ministry of Health (Grant No 13186) during the conduct of the study. M Dolzhenko reports Grants from Universal agency "Profama" of Ukraine during the conduct of the study. P Amouyel reports personal fee from Servier, Hoffman Laroche, Total, Genoscreen, Alzprotect and Foundation Plan Alzheimer outside the submitted work. S Törk reports Grants from German Federal Ministry of Research (BMBF, Berlin, Germany: BMBF 01E01004) during the conduct of the study. Z. Reiner reports personal fees from AstraZeneca, Abbot, Sanofi and Synageva outside the submitted work.

Received: 29 July 2015 Accepted: 24 September 2015 Published online: 01 October 2015

\section{References}

1. Norhammar A, Tenerz Å, Nilsson G, Hamsten A, Efendic S, Rydén L, Malmberg K. Glucose metabolism in patients with acute myocardial infarction and no previous diagnosis of diabetes mellitus: a prospective study. Lancet. 2002;359(9324):2140-4.

2. Tierney EF, Geiss LS, Engelgau MM, Thompson DJ, Schaubert D, Shireley LA, et al. Population-based estimates of mortality associated with diabetes: use of a death certificate check box in North Dakota. Am J Publ Health. 2001;91(1):84-92.

3. International Diabetes Federation. IDF Diabetes Atlas teB, Belgium: International Diabetes Federation; 2011. http://www.idf.org/diabetesatlas. Accessed 3 Dec 2014

4. Norhammar A, Lindbäck J, Rydén L, Wallentin L, Stenestrand U. Improved but still high short- and long-term mortality rates after myocardial infarction in patients with diabetes mellitus: a time-trend report from the Swedish Register of Information and Knowledge about Swedish Heart Intensive Care Admission. Heart. 2007;93(12):1577-83.
5. De Bacquer D, De Backer G, Ostor E, Simon J, Pyörälä K. Predictive value of classical risk factors and their control in coronary patients: a follow-up of the EUROASPIRE I cohort. Eur J Cardiovasc Prev Rehab. 2003;10(4):289-95.

6. Anselmino M, Malmberg K, Öhrvik J, Rydén L. Evidence-based medication and revascularization: powerful tools in the management of patients with diabetes and coronary artery disease: a report from the Euro Heart Survey on diabetes and the heart. Eur J Cardiovasc Prev Rehab. 2008;15(2):216-23.

7. Anselmino M, Bartnik M, Malmberg K, Rydén L. Management of coronary artery disease in patients with and without diabetes mellitus. Acute management reasonable but secondary prevention unacceptably poor: a report from the Euro Heart Survey on Diabetes and the Heart. Eur J Cardiovasc Prev Rehab. 2007;14(1):28-36.

8. Gyberg V, Kotseva K, Dallongeville J, Backer GD, Mellbin L, Rydén L, et al. Does pharmacologic treatment in patients with established coronary artery disease and diabetes fulfil guideline recommended targets? A report from the EUROASPIRE III cross-sectional study. Eur J Prev Cardiol. 2014;e-publ. doi:10.1177/2047487314529353.

9. Perk J, De Backer G, Gohlke H, Graham I, Reiner Z, Verschuren VM, et al. European Guidelines on cardiovascular disease prevention in clinical practice (version 2012): the Fifth Joint Task Force of the European Society of Cardiology and Other Societies on Cardiovascular Disease Prevention in Clinical Practice. Atherosclerosis. 2012;223(1):1-68.

10. Rydén L, Standl E, Bartnik M, Van den Berghe G, Betteridge J, de Boer MJ, et al. Guidelines on diabetes, pre-diabetes, and cardiovascular diseases: executive summary. The Task Force on Diabetes and Cardiovascular Diseases of the European Society of Cardiology (ESC) and of the European Association for the Study of Diabetes (EASD). Eur Heart J. 2007;28(1):88-136.

11. Rydén L, Grant PJ, Anker SD, Berne C, Cosentino F, Danchin N, et al. ESC Guidelines on diabetes, pre-diabetes, and cardiovascular diseases developed in collaboration with the EASD: the Task Force on diabetes, pre-diabetes, and cardiovascular diseases of the European Society of Cardiology (ESC) and developed in collaboration with the European Association for the Study of Diabetes (EASD). Eur Heart J. 2013;34(39):3035-87.

12. Kotseva K, Wood D, De Bacquer D, De Backer G, Rydén L, Jennings C, et al. EUROASPIRE IV: a European Society of Cardiology survey on the lifestyle, risk factor and therapeutic management of coronary patients from twenty-four European countries. Eur J Prev Cardiol. 2015. pii: 2047487315569401. [Epub ahead of print].

13. Lean MEJ, Han TS, Morrison CE. Waist circumference as a measure for indicating need for weight management. BMJ. 1995;311(6998):158-61.

14. Middleton ET, Morice AH. Breath carbon monoxide as an indication of smoking habit. Chest. 2000;117(3):758-63.

15. Hannestad U, Lundblad A. Accurate and precise isotope dilution mass spectrometry method for determining glucose in whole blood. Clin Chem. 1997;43(5):794-800.

16. Carstensen B, Lindström J, Sundvall J, Borch-Johnsen K, Tuomilehto J. Measurement of blood glucose: comparison between different types of specimens. Ann Clin Biochem. 2008;45(Pt 2):140-8.

17. Brown H, Prescott R. Applied mixed models in medicine. 2nd ed. New York: Wiley; 2006.

18. Gyberg V, De Bacquer D, Kotseva K, De Backer G, Schnell O, Sundvall J, et al. Screening for dysglycaemia in patients with coronary artery disease as reflected by fasting glucose, oral glucose tolerance test, and $\mathrm{HbA} 1 \mathrm{c}$ : a report from EUROASPIRE IV-a survey from the European Society of Cardiology. Eur Heart J. 2015. doi:http://dx.doi.org/10.1093/eurheartj/ehv008. First published online: 10 Feb 2015.

19. Barengo NC, Tuomilehto JO. Blood pressure treatment target in patients with diabetes mellitus_current evidence. Ann Med. 2012;44(Suppl 1):S36-42.

20. Mancia G, Schumacher H, Redon J, et al. Blood pressure targets recommended by guidelines and incidence of cardiovascular and renal events in the Ongoing Telmisartan Alone and in Combination With Ramipril Global Endpoint Trial (ONTARGET). Circulation. 2011;124(16):1727-36.

21. Gaede $\mathrm{P}$, Lund-Andersen $\mathrm{H}$, Parving HH, Pedersen $\mathrm{O}$. Effect of a multifactorial intervention on mortality in type 2 diabetes. New Engl J Med. 2008;358(6):580-91.

22. Gaede P, Pedersen O. Intensive integrated therapy of type 2 diabetes: implications for long-term prognosis. Diabetes. 2004;53(Suppl 3):S39-47. 
23. Sacks FM, Hermans MP, Fioretto P, Valensi P, Davis T, Horton E, et al. Association between plasma triglycerides and high-density lipoprotein cholesterol and microvascular kidney disease and retinopathy in type 2 diabetes mellitus: a global case-control study in 13 countries. Circulation. 2014;129(9):999-1008.

24. Tight blood pressure control and risk of macrovascular and microvascular complications in type 2 diabetes: UKPDS 38. UK Prospective Diabetes Study Group. BMJ. 1998;317:703-13.

25. Kotseva K, Wood D, De Backer G, De Bacquer D, Pyörälä K, Keil U. EUROASPIRE III: a survey on the lifestyle, risk factors and use of cardioprotective drug therapies in coronary patients from 22 European countries. Eur J Cardiovasc Prev Rehab. 2009;16(2):121-37.

26. Intensive blood-glucose control with sulphonylureas or insulin compared with conventional treatment and risk of complications in patients with type 2 diabetes (UKPDS 33). UK Prospective Diabetes Study (UKPDS) Group. Lancet. 1998;352(9131):837-53.

27. Skyler JS, Bergenstal R, Bonow RO, Buse J, Deedwania P, Gale EA, et al. Intensive glycemic control and the prevention of cardiovascular events: implications of the ACCORD, ADVANCE, and VA Diabetes Trials: a position statement of the American Diabetes Association and a Scientific Statement of the American College of Cardiology Foundation and the American Heart Association. J Am Coll Card. 2009;53(3):296-304.
28. Holman RR, Paul SK, Bethel MA, Matthews DR, Neil HA. 10-Year followup of intensive glucose control in type 2 diabetes. New Engl J Med. 2008;359(15):1577-89.

29. Sánchez RCC, Carcía J, Tuomilehto J, Rydén L. EuroHeart II project. Work Package 9. Second Programme of Community Action in the Field of Health (2008-2013). 2014

30. Wood DA, Kotseva K, Connolly S, Jennings C, Mead A, Jones J, et al. Nurse-coordinated multidisciplinary, family-based cardiovascular disease prevention programme (EUROACTION) for patients with coronary heart disease and asymptomatic individuals at high risk of cardiovascular disease: a paired, cluster-randomised controlled trial. Lancet. 2008;371(9629):1999-2012.

31. Moe B, Augestad LB, Nilsen TIL. Diabetes severity and the role of leisure time physical exercise on cardiovascular mortality: the Nord-Trondelag Health Study (HUNT), Norway. Cardiovasc Diabetol. 2013;12:83-90.

32. Ferrari R. EURObeservational Research Programme. Europ Heart J. 2010;31:1023-31

\section{Submit your next manuscript to BioMed Central and take full advantage of:}

- Convenient online submission

- Thorough peer review

- No space constraints or color figure charges

- Immediate publication on acceptance

- Inclusion in PubMed, CAS, Scopus and Google Scholar

- Research which is freely available for redistribution

Submit your manuscript at

www.biomedcentral.com/submit

() Biomed Central 